\title{
The Relation Between FDI and Unemployment : An Empirical Study on Egypt
}

Rooye Mohammed Said, Aya Anas Abd Al Baqy, Hania Amr Mohammed, Salma Alaa EI Den Okasha, Sara Mostafa Shaaban

Graduates of Faculty of Economics and Political Science

- Cairo University

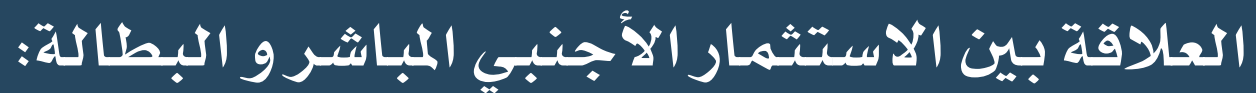

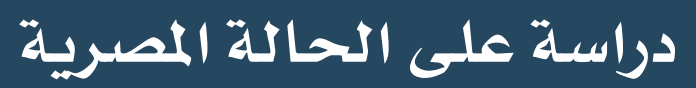

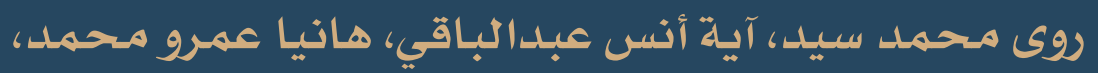

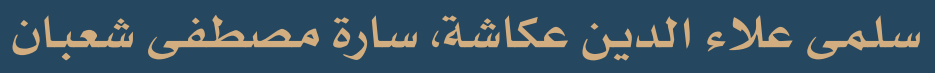

$$
\begin{aligned}
& \text { من خريجي كلية الاقتصاد والعلوم السياسية - جامعة القاهرة }
\end{aligned}
$$

(*) The research was supervised by Dr. Marwa Mamdouh, Assistant Professor at Faculty of Economics and Political Sciences, Cairo University.

mmsm@feps.edu.eg

Correspondence:

Rooye Mohammed Said, Aya Anas Abd Al Baqy, Hania Amr Mohammed, Salma Alaa El Den Okasha, and Sara Mostafa Shaaban Mostafa.

Graduates of Faculty of Economics and Political Science- Cairo University

E-mail: rawa.mohammed2017@feps.edu.eg, Aya.Anas2017@feps.edu.eg, Hania.Amr2017@ feps.edu.eg, Salma.aladdin2017@feps.edu.eg, sarah.mostafa2017@feps.edu.eg

Citation: Rooye Mohammed Said et al., "The Relation Between FDI and Unemployment : An Empirical Study on Egypt for the Period", The International Journal of Public Policies in Egypt, IDSC, Volume (1), Issue (1), January 2022, pp. 116-138 


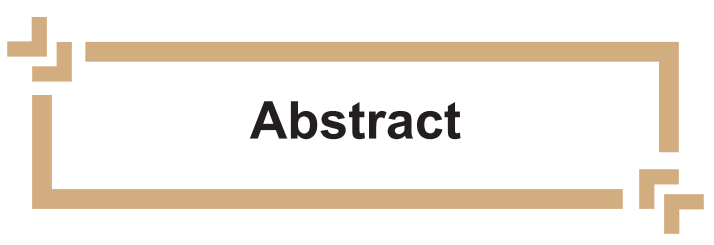

The relation between foreign direct investment (FDI) and unemployment is one of the most controversial relationships in economic literature as there is no consensus on this relation and it differs from one country to another. The aim of this paper was to examine and analyze the relation between FDI and unemployment in Egypt from 1990 to 2019 to examine if FDI helps in reducing the chronic unemployment problem or not. The paper provides qualitative analysis, which includes analysis of the trend of FDI and unemployment, as well as policies adopted by the Egyptian government aiming at encouraging FDI like enacting Capital Market Law No. 95 of 1992, Law No.3 of 1997 and Investment Law No. 72 of 2017, GAFI was mandated to develop an investment map in cooperation with all concerned country's authorities. To add up to that, the paper analyzed the policies and initiatives developed by the government from 1990 to 2019 to reduce unemployment.

In addition to the qualitative analysis, the paper provides quantitative analysis through using the Ordinary Least Squares method (OLS) for estimating the econometric model. The dependent variable in the model was unemployment rate and the independent variables were net FDI inflows as a percentage of GDP, exports as a percentage of GDP, annual growth rate of GDP and annual inflation rate measured by consumer price index (CPI). The main findings were that there is a positive significant relation between FDI and unemployment in Egypt. This might be due to the fact that FDI is directed towards capital-intensive industries as well as short term employment labor intensive industries. Thus, the paper suggested that the Government should be working to attract FDI in labor-intensive industries that relies on local products and expertise in sectors that do not provide only seasonal or short-term employment and improving the quality of labor through providing training programs that can improve their skills and add to their knowledge so as to increase the relative competitiveness of the domestic labor.

Keywords: Unemployment, FDI, Investment laws, Egypt, Labor market programs 


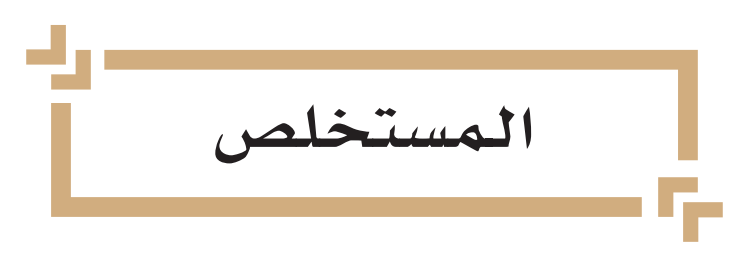

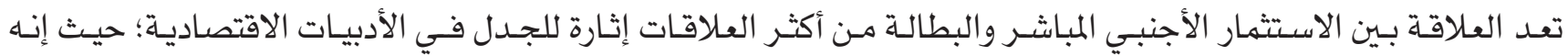

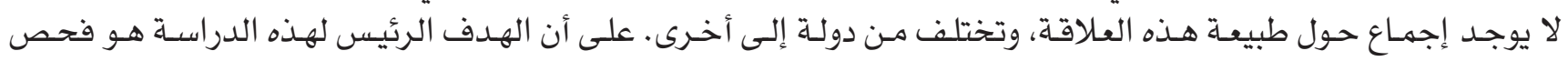

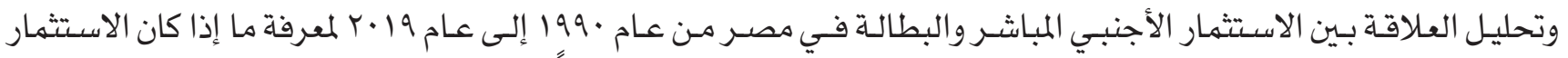

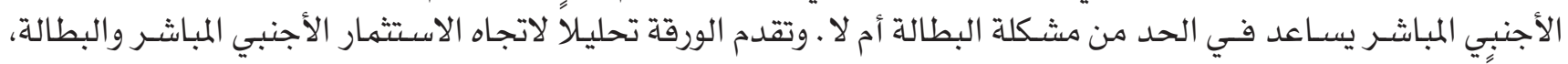

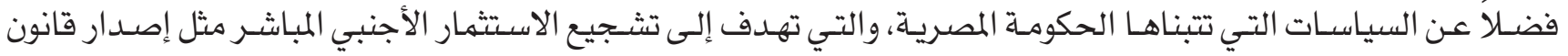

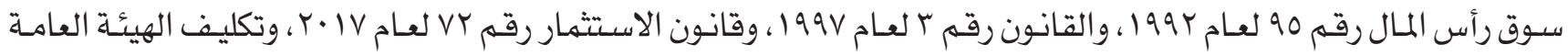

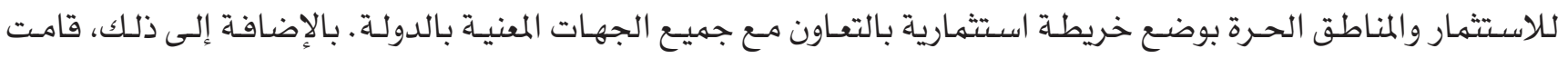

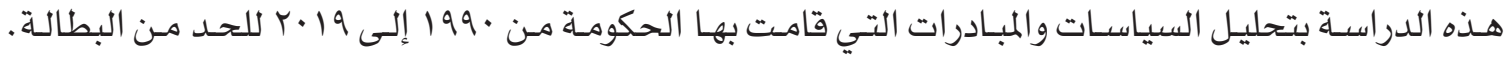

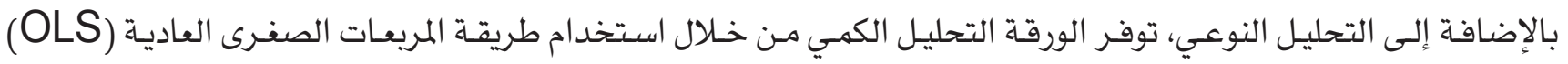

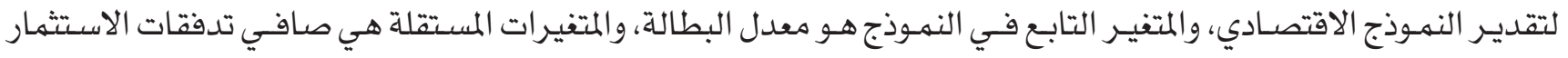

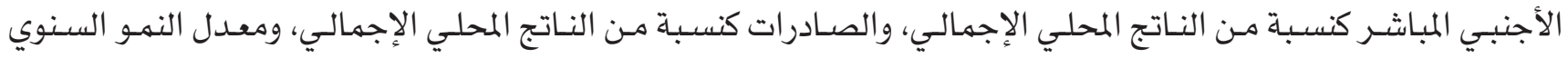

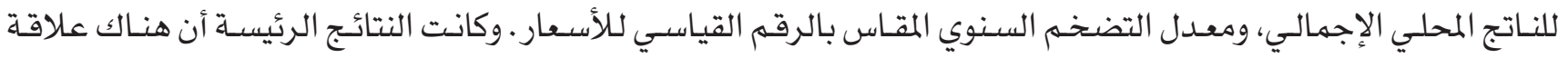

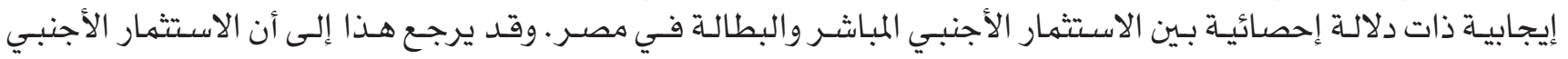

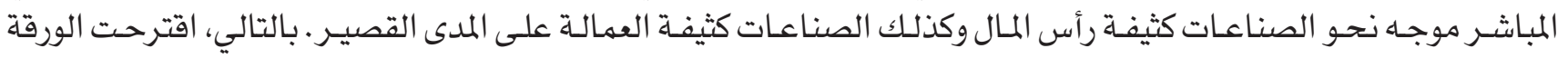

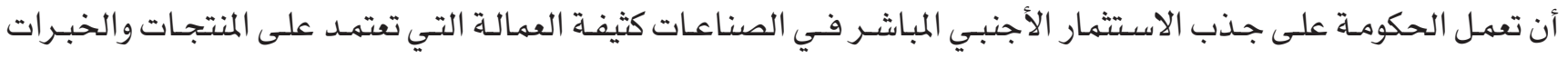

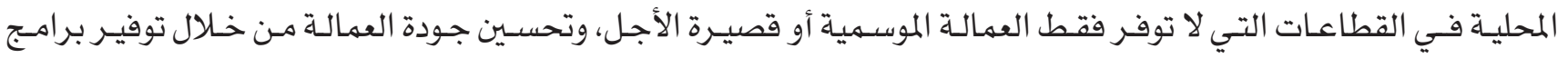

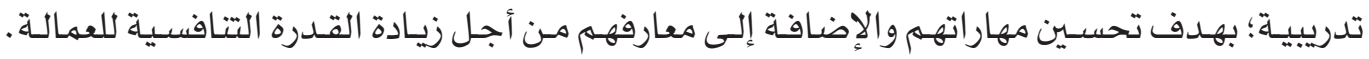
الكلمات المفتاحية: البطالة - الاستثمار الأجنبي المباشر - قوانين الاستثمار - مصر - برامج سوق العمل 


\section{Introduction}

It is well known that the four major economic policy objectives are: full employment, price stability, high and sustainable rate of economic growth, and keeping the balance of payments in equilibrium (Grahovac, Softic, 2017). However, no developing country is self-reliant to achieve the optimum level of many of those objectives without overseas capital. This could be attributed that developing and emerging countries endure many economic shortcomings and development challenges. Some of those critical shortcomings are the inability to reduce unemployment, low domestic saving rates and inefficient financial intermediaries. Thus, the domestic investment is not sufficient for the development process and the overseas capital in the form of foreign direct investment (FDI) is requisite to supplement its growth objectives. Therefore, foreign direct investments have been regarded in the last years by the governments of the developing countries as one of the best alternatives to fuel their economic growth, meet their investment needs and compensate for their shortcomings (Alalawneh and Nessa, 2020).

Compared to other African and Middle Eastern countries, Egypt is one of the highest FDI recipients in Africa in 2019 with a stock of USD 126.6 billion (UNCTAD, 2020). Thus, Egypt can use FDI as an essential source for job creation with better wages, as well as improving the quality of goods and services, which might result in reducing the chronic unemployment problem. Having this high level of FDI in Egypt makes the relation between FDI and unemployment clearer to detect. That's why, Egypt will be the developing country under study throughout this research paper.

In an attempt to reach the aim of the paper, this research paper will be divided into five sections. The second section will tackle the theoretical background for the studied relation, as well as viewing the empirical results of this relation in a number of countries. The section that follows includes a general overview for the most important FDI policies and active labor market programs throughout the period under study, in addition to a qualitative analysis for the trend of FDI and unemployment simultaneously. The fourth section will analyze the proposed relation quantitatively using an econometric model, and then some recommendations will be suggested. The last section will summarize the main findings of the paper. 


\section{1- Literature Review}

\section{1-1 Theoretical Framework}

There exist different theories and hypotheses that provide linkages between unemployment and certain macroeconomic variables such as inflation, output and foreign direct investment (FDI). The relationship between unemployment and FDI was viewed from different theoretical angels. Therefore, this section will be divided into two subsections: the first is to study the different theories that illustrated the relationship between FDI and unemployment, while the second will view the findings of different studies regarding the proposed relationship.

Holte (1998) is one of the theories, which proposed that there is a negative relation between FDI and unemployment. He added that the government could make use of this relationship by reducing high unemployment rate through its choice of economic policies. (Onanuga et al, 2018).

Moreover, Keynes viewed the negative relation between FDI and unemployment. He stated that unemployment, which was caused by a gap between consumption and income due to a decline in total effective demand in time of recessions, need to be reduced by supporting investment opportunities, whether domestically or internationally (FDI). That is, he asserted that FDI could have a negative influence on unemployment (Ezzat, 2019).

Furthermore, the insider-outsider theory argued that FDI won't lead to employment loss, on the contrary, FDI can create new job opportunities besides preserving the existing ones. (Ezzat, 2019).

On the other hand, Ricardo (1821) supported the positive relation between FDI and unemployment through formulating jobless growth theory which states that there is a negative relationship among investment, output expansion and job creation because capital investment is a perfect substitute for labor in the economy. Thus, when FDI inflow adopts capital-intensive production techniques within its MNCs, this reduces the demand for labor, thus raising unemployment.

Moreover, Pigou's theory supported the positive correlation between FDI and unemployment but according to the theory the relation runs from unemployment to FDI. Pigou's theory suggests that a high unemployment rate in a country can be perceived by foreign investors as a signal of macroeconomic disequilibrium and such countries are not seen as an appropriate host country for foreign investments (Onanuga et al, 2018).

The contradiction previously discussed among the theories regarding the direction and magnitude of the relation between FDI and unemployment could be explained through several channels that may be at work when analyzing the influence of FDI on unemployment. Some of those channels are direct and others are indirect, each of which could be positive or negative. FDI can increase employment directly 
through creating new jobs in foreign affiliates and decrease it through loss of employment (Chetri et al, 2020). Greenfield investment is supposed to have the highest potential for employment creation (Jude et al, 2016). This can be attributed to expanding the overall market size, which would generate increased competition for the limited pool of labor resources resulting in increasing in labor demand and creating new jobs that did not exist before (Golejewska, 2001).

Nevertheless, FDI doesn`t only create new job opportunities but can also lead to a decrease in employment. This could occur in the case of Brownfield investment such as mergers and acquisitions because they merely transfer responsibility for existing employees (Onanuga et al, 2018), These direct effects are accompanied by indirect effects, that is, influencing the labor demand of domestic firms, through both competition effects and productivity spillovers. These indirect effects (spillovers) can take many forms, for instance, it can take place through movement of trained labor from foreign firms to other sectors where they become more productive resulting in positive technology spillovers (Abouelfarag et al, 2018).

Therefore, these channels may act in opposite directions resulting in an ambiguous net effect of FDI on unemployment. This net effect depends on the relative importance of the net creation of activity, resource endowments and development levels of the host country, the sector and industry of the investment, the international production strategies of MNCs, the productivity improvements and the spillovers to domestic firms and host country policy towards FDI (Golejewska, 2001).

\section{1-2 Empirical Review}

The empirical literature can be divided into three broad groups. The first group concluded that FDI reduced unemployment in the host country, accordingly, there is negative relation between FDI and unemployment. The second argued that there is a positive relation between FDI and unemployment. The third group found no relation between FDI and unemployment.

Concerning the studies that found a negative relation between foreign direct investment and unemployment, Balcerzak and Zurek (2011) studied the impact of foreign direct investment on the labor market in Poland. The quarterly data for unemployment and FDI from 1995 to 2009 was used in the research paper. The Vector Autoregressive model (VAR) was employed in the study using Schwartz criterion to investigate the relation between FDI and unemployment. It was concluded that there is interdependency between FDI and unemployment and that in the short run FDI has the potential to reduce unemployment.

Moreover, WIDIA et al. (2019) used cross sectional data for countries of the Association of Southeast Asian Nations to investigate the potential for FDI to reduce unemployment in the region. The study used annual data from 1975 to 2016 for the Philippines, Indonesia, Thailand, Singapore and Malaysia. 
By employing a series of Vector Error Correction Model (VECM), it was concluded that FDI have the potential to reduce unemployment in the five Asian countries.

On the contrary, some studies observed a positive relationship between FDI and unemployment where Bayar and Sasmaz (2017) suggested that brownfield investment was the cause of a positive relationship between FDI and unemployment among 21 emerging economies. A Wusterland-DurbinHausman's co-integration test and Augmented Mean Group (AMG) were used to study the long run effect of FDI on unemployment for the period 1994-2014. Results showed an insignificant effect of FDI inflows on unemployment in Egypt, South Africa, Greece, Hungary, Indonesia, Chile, Qatar, Peru and Malaysia. While a positive effect between FDI and unemployment was incurred in Brazil, China, Czech Republic, India, Korea, Poland, Thailand and Turkey.

Bayar (2014) analyzed the relationship between economic growth, unemployment and foreign direct investment inflows in Turkey. Data from the Turkish Statistical Institute and Central Bank of the Republic of Turkey covering the period of 2000 to 2013 was used in auto-regression distributed lag model. The findings showed a positive relationship between FDI and unemployment, where a $1 \%$ increase in FDI inflows led to $0.46 \%$ increase in unemployment.

On the other hand, some studies reached no relation between FDI and unemployment. Aktar and Ozturk (2009) used variance decomposition and impulse response function analysis using Vector Autoregressive model (VAR) to study the relation between foreign direct investment GDP, exports and unemployment in Turkey using quarterly annual data from 2000 to 2007 . The results show that FDI in Turkey does not have the potential to reduce unemployment rate in the short run.

Nampasa and Andrew (2017) aimed to study the relationship between FDI, domestic investment and unemployment in South Africa from 1970 to 2014. Quarterly data from the World Bank and African Reserve Bank was used. A three stages autoregressive distributive lag (ARDL) co-integration model was applied to analyze the time-series relationship between the variables. The results revealed a significant co-integration between the three variables. However, there was no significant effect of FDI on reducing unemployment rate in the country.

After reviewing the literature, it is evident that there is no general consensus on the nature of the relation between the FDI and unemployment. The different results reached by these studies are due to differences in each country political, economic and social system, labor market structure and the type of FDI. Since unemployment is a major problem in Egypt as a developing country and FDI might be a potential solution to face this problem, then this paper will seek to examine the relationship between FDI and unemployment in Egypt using recent figures of FDI and unemployment. Therefore, the next two sections will be an attempt to study this relation in Egypt within the period from 1990 to 2019. 


\section{2- Unemployment and FDI in Egypt (1990-2020)}

The past thirty years within the history of Egypt witnessed three main turning points in the Egyptian economy, in which unemployment rate and FDI had some fluctuations. The first turning point was the Economic Reform and Structural Adjustment Program in 1990. After about eleven years, Egypt has some serious political and economic disturbances due to the 25th January Revolution and in 2016, another economic reform program was held by the government in the form of "Egypt Vision 2030". Therefore, this section will be divided into three subsections. The first subsection is to present the evolution of FDI policies, followed by the second subsection, which will tackle different Active Labor Market Programs (ALMPs). Then, the third subsection that will analyze the trend of FDI net inflows and unemployment rate.

\section{2-1 Foreign Direct Investment Policies in Egypt (1990-2020)}

With the wide spread of globalization and the diminishing number of closed economies, foreign direct investment (FDI) became of a great concern to every country especially for developing countries. Thus, it is crucial for Egypt to seek higher FDI due to its ability to compensate for its declining national saving rate especially during the last decade (Mahboub, 1998). That's why, since the Egyptian Government launched the economic reform program in the 1990s, it has been initiating several laws and policies to regulate FDI in Egypt as a host country in the period from 1990 to 2020.

In the 1990s, Egypt aimed at attracting more FDI through the improvement of its legal and institutional environment (UNCTAD, 1999). Few important laws were enacted during this decade such as Capital Market Law No. 95 of 1992, Law No.3 of 1997 and Investment Law No.8 of 1997(Soliman \& Youssef, 2020). The Investment Law No.8 of 1997 was considered one of the key laws in the 1990s filling the gaps in the Companies Law No.159 of 1981. It regulated the ownership of real estate by foreigners through allowing complete foreign ownership of the Egyptian state; however, the approval was required for all foreign companies but it did not require a specific restriction on the Egyptian's equity share. In addition, it granted custom exemptions such as a unified rate of $5 \%$ on the value of machines, equipment and instruments imported (UNCTAD, 1998).

On the other hand, since 2001, FDI has faced some challenges in Egypt because of bureaucracy that caused delays for startups as well as existing investments resulting in a decline in FDI. That's why, in 2001, the Egyptian government started reorganizing the GAFI (Stone, 2006).

After the financial crisis in 2008, the Egyptian authorities found a persisting need for recovering investors' trust in the Egyptian economy. Accordingly, Egypt has signed 113 bilateral investment treaties by 2013. Furthermore, some substantial amendments were enacted in 2015 to the Investment Law of 1997. (OECD, 2021). 
In an attempt to overcome the deficiencies of Investment Law of 1997 and its amendments, lining with the implementation of the economic reform in 2016, the GAFI and Ministry of Investment and International Cooperation (MIIC) issued the Investment Law No. 72 of 2017 replacing law No.8 of 1997. In order to enhance the overall investment environment, the law worked on merging the scattered laws and regulations under legislation (OECD, 2021). The economic reforms implemented in 2016 and Investment law of 2017 were able to stabilize macroeconomic and political conditions.

An Investor Service Centre was established by the GAFI to be more responsive to investors' needs. In an attempt to facilitate the access and registrations for land, GAFI was mandated to develop an investment map in cooperation with all concerned country's authorities (OECD, 2020). In 2018, the first phase of the initiative was launched followed by the second in 2019 encompassing 2,000 new projects (COMESA, 2021).

The Collateral Registry Law No.115 of 2015 facilitated the utilization of movable assets as collaterals by investors as well as establishing electronic collateral registry (OECD, 2021). In the same year, the Law of Restructuring, Preventive Reconciliation and Bankruptcy in Egypt has been enacted (OECD, 2021). Since the enactment of these laws, Egypt's rank in the World Bank resolving insolvency index has increased from 115 to 104 (OECD, 2021).

In 2020 despite the COVID-19 negative effects on Egypt's external finances, GDP growth and fiscal performance, the reforms in all spectrums have enabled Egypt with a degree of flexibility to overcome this shock. In this essence, the Government has enacted 2020 Custom Law, which targeted the promotion of FDI to ease the international trade procedures in the country as well as enhancing the single window system electronic payments. As a result of these improvements in the legislative environment since 2016 Egypt's rank has been raised six ranks in the World Bank's Doing Business 2020 to stand at 114 out of 190 countries (Amcham Egypt, 2021).

\section{2-2 Active Labor Market Programs (ALMPs) in Egypt (1990-2020)}

Unemployment in Egypt has been a major problem that all governments have tried to control and solve due to its negative impact on the economy. That's why, reducing unemployment, especially among young age groups (15-29) where unemployment is concentrated has been a major priority in nearly all governments`agendas especially the developing ones (Barsoum, 2016). Thus, this section will highlight the most important ALMPs from 1990 to 2020.

The starting point of the period under study is 1990 at which the government decided to adopt the Economic Reform and Structural Adjustment Program (ERSAP) in cooperation with the International Monetary Fund and the World Bank to solve the major macroeconomic imbalances, reduce inflation and combat aggregate demand. According to the ERSAP, it was obligatory that the Government decreases employment in the public sector, which was considered the main employer. Thus, several structural 
reforms were implemented such as downsizing government spending, implementing privatization, laying out workers and decreasing government's role in the economy, which in turn contributed to increasing unemployment during the 1990s (Amer, 2012).

Thus, in order to mitigate the increasing unemployment in 1990s, the Social Fund for development (SFD) was established in 1991 with some objectives. The main objectives were reducing unemployment, setting development strategy for small and medium enterprise (SMEs) sector and creating new jobs through supporting entrepreneurship. The focus of the Egyptian government during this decade was supporting self-employment and skill development programs. As a result, an important initiative was introduced in 1994, which is Mubarak kohl initiative (Amer, 2012).

The beginning of the 2000s was marked by the formulation of the National Youth Employment Strategy (NYES) in July 2001 under the supervision of the prime minister's cabinet at that time. It was an ambitious attempt toward establishing a strategy for youth employment with a total cost of 5 billion dollars.. (Amer, 2012)

Then, the National Training Fund was established in 2003 with the aim of creating, funding, developing and enhancing training programs in Egypt. It was funded from the government, donations and cutting $1 \%$ of enterprises profits (Amer, 2012)

After 2011 and the 25th January Revolution, the unemployment rate increased significantly to be $11.85 \%$ in 2012. Thus, there were comprehensive projects that combined different types of active labor market polices such as skills development, employment services and entrepreneurship promotion. For instance, between 2011 and 2014, the Neqdar Nesharek project, which means "we can participate" in Arabic, was initiated with the assistance of the Population Council and International Labor Organization (ILO) in thirty rural villages where young women are especially vulnerable to economic marginalization. (Population Council, 2014)

From 2011 to 2020, the ILO with the support of the Global Affairs Canada (GAC) established ILO's Decent Jobs for Egypt's Young People (DJEP) project. The project aimed to create decent work opportunities for young men and women in the Egyptian Governorates of Minya, Port-Said, Red Sea and Luxor. The project was held in two phases. Nevertheless, this program aimed to improving governorates within four approaches of sustainable development: green jobs, social economy, gender equality and inclusion of persons with disabilities. (ILO, 2021)

Moreover, large public works programs were initiated after 2011 such as the Emergency Labour Intensive Investment Project and the Emergency Employment Investment. In 2015, the Emergency Labour Intensive Investment Project (ELIIP) was initiated by the World Bank in Egypt. The objectives of ELIIP for Egypt are creating short-term employment opportunities for the unemployed who are unskilled and semi-skilled workers, as well as providing access to basic infrastructure services to the 
targeted population in poor areas. (World Bank Group, 2015).

In 2016, the sustainable development plan in Egypt "Egypt Vision 2030" aimed to achieve some active labor market policies in its economic, educational and cultural sections. Those polices work in harmony to reach a targeted unemployment rate of 5 per cent in 2030. This could be achieved through increasing vocational training opportunities and creating decent and productive job opportunities in the non-traditional industry and culture sectors (ILO, 2017)

In 2019 and 2020, the corona virus had affected the Egyptian labor market significantly. The pandemic caused a sharp decline in the exports, imports, tourism and almost all the economic sectors activities all over the country. Accordingly, companies, factories and small enterprises had to lay off workers or cut wages to be able to continue operating throughout this crisis. Thus, the government had to stimulate the economy and employment through adopting active fiscal and monetary policies. That's why, the Central Bank launched an initiative in March 2020 to postpone the repayment of the loan installments and credit card dues for 6 month in order to mitigate the effects of the corona virus on the Labor force and prevent the default of some enterprises (The Egyptian Center for Economic Studies, 2020).

\section{2-3 Trend of FDI and Unemployment Rate in Egypt (1990-2020)}

It is observed from the previous two sections that there is much attention directed towards increasing FDI and reducing unemployment rate in Egypt from 1990-2020, but were changes in FDI associated with changes in unemployment rate? In an attempt to answer this question, the trend of FDI net inflows and unemployment rate will be analyzed simultaneously in Egypt from 1990 to 2019 as shown in figure (1):

Figure (1): FDI net inflows and Unemployment rate in Egypt (1990-2019)

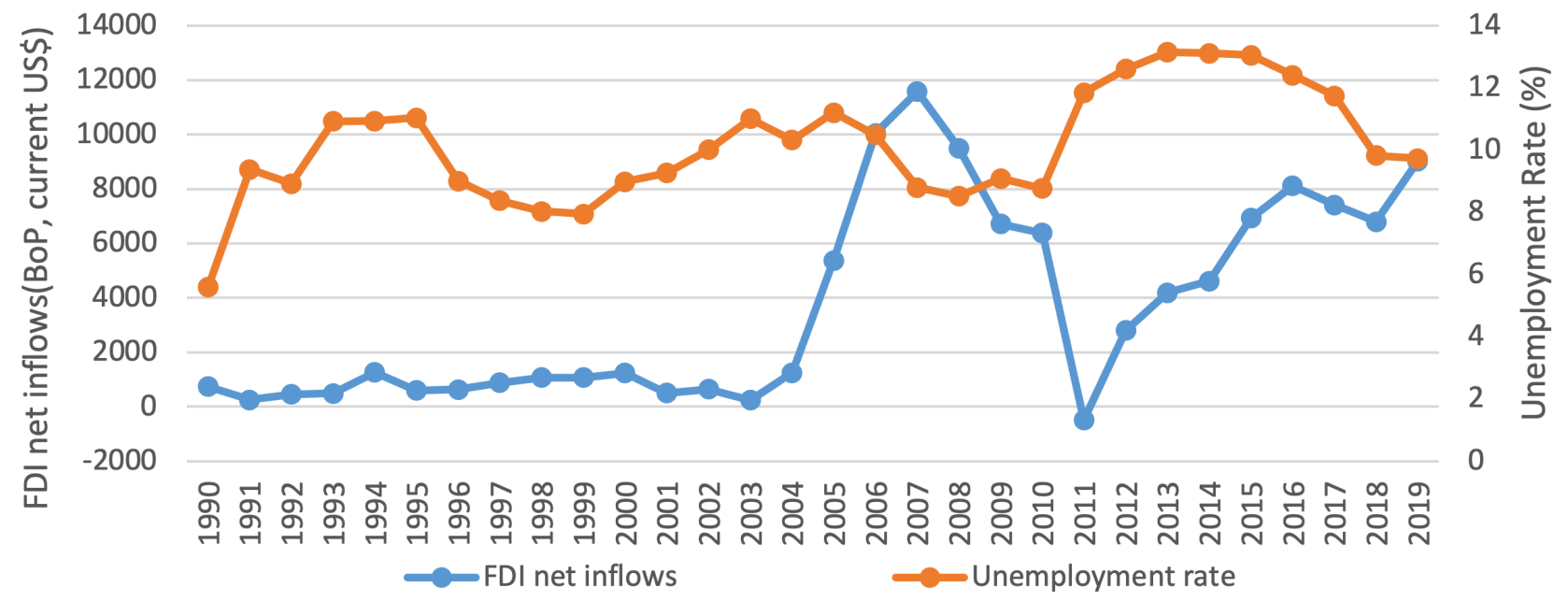

Source: prepared by the researcher based on the World Bank Data 
It can be noticed that from 1990 to 2019 , the level of FDI and unemployment were highly fluctuating. From year 1990 to 2003, level of FDI net inflows were slightly fluctuating, while the unemployment rate had some fluctuations as well as maintaining a high value. That is, after increasing dramatically from $5.6 \%$ in 1990 to $9.38 \%$, it ranged from above $8.3 \%$ to $11 \%$ for the rest of the period. On the other hand, the level of FDI net inflows was relatively small and had a constant trend. It is also found that although Egypt was the largest recipient of FDI in North Africa from 1995 to 2000 (Saleh, 2015), the level of inflows was very small whether compared to the inflows of other developing countries, or to the rest of the time series. The level of FDI inflow decreased to a minimum of 237.4 million USD in year 2003.

Moreover, FDI net inflows were low from the 1980s till 1993 as there were some persistent macroeconomic problems that Egypt faced as a result agreements with the World Bank and the IMF were signed in 1990s, which included reform programs that aimed at liberalizing and privatizing the economy, which in turn, encouraged FDI inflows (Aboel Farag, Abed, 2018). However, unemployment rate was slightly fluctuating with high values (Haq, Zaki, 2015) for two main reasons. First, it was affected by privatization policies enacted before the 1990s reform programs, which resulted in an overemployed and inefficient public sector whose wage burden constituted a huge share of the government expenditure (Said, 2015). The second reason is the inability of economic policies to achieve high labor intensive growth as capital accumulation was the main driving force for production in this period (Haq, Zaki, 2015).

In addition, the Egyptian economy in 1998 faced external shocks such as the reduction in oil prices, the famous incident of Luxor in 1997, 1997-1998 East Asian economic crises, the attack of 11 September in 2001, and the war of Iraq (Masry 2015). There were also internal events including the pressure on the balance of payments current account due to external factors, devaluation of the Egyptian pound in 2001, growth rate decline, and increase in the inflation rate. These political and economic conditions affected the investment environment, and decreased the attractiveness of the Egyptian economy to FDI inflows throughout this period. These reasons were associated with the incomplete reforms in the labor and financial markets based on the agreement between Egypt and the EU that was signed in 2001 ,which also contributed in the rising unemployment in the early 2000s (Aboel Farag and Abed, 2018).

After 2003, FDI net inflows increased to USD 1.253 billion in 2004, and reached its peak in 2007 at USD 11.2781 billion, while the unemployment rate was almost stable from 2003 to 2005 . Then, it started to decrease until it reached $8.52 \%$ in 2008 , and $8.76 \%$ in 2010 . This increase in FDI and decrease in unemployment rates could be justified by the appointment of the new cabinet in 2004 and the subsequent improvement in investment climate, which increased the attractiveness of Egypt for 
investment (Aboel Farag and Abed, 2018), whether domestic or foreign. Another reason is the public enterprises acquisition, privatization, and merges in this period. (Masry 2015). In addition, GDP growth was higher and was more job-rich as 2.5 million job opportunities were newly created between 2005 and 2007 (World Bank).

In the period after 2007, the level of FDI started to decrease drastically. Obviously, because of the global market crisis in 2008, and its effect on the global economy (Aboel Farag and Abed, 2018), FDI declined to 6.711 billion USD, however, this was not yet reflected on unemployment as it was still declining until it reached $8.76 \%$ in 2010 . This might be the impact of continuous reforms, in addition that the growth in Egypt at this time was mainly labor-intensive in the fields of agriculture, services, and construction (World Bank).

Due to the political and security challenges that was specifically brought by the 25th of January Revolution in 2011, the FDI inflow reached its minimum value within the whole time series with a value of USD -482.7 million, and the unemployment rate highly increased by about 3\% from $8.76 \%$ in 2010 to $11.58 \%$ in 2011 . FDI redeemed to a positive value again in 2012 at USD 2.797 billion due to the support of Qatar (Masry, 2015). However, unemployment rate was still rising until it reached 13.15\% in 2013 and $13.05 \%$ in 2017 , this was because it was also highly affected by the political instability and the consequences of the revolution on the economy. Thus, the labor market did not manage to recover as fast as FDI from the recession prevailed in the goods market as well as the deterioration of the tourism sector (Said, 2015).

The FDI inflows was then increasing and reached USD 8.106 billion in 2016, and was ranked as the fourth African country attracting FDI in this year. Moreover, unemployment rate started to decrease in year 2016. This is due to the relative recovery of the Egyptian economy after the political instability in 2011. This recovery could be attributed to the new investment law amendments conducted in 2015 that aimed at encouraging foreign investments through introducing a number of policies including tax and nontax incentives, subsidizing training programs for employees, allocating lands at reduced prices, facilitating market exit processes, authorization of the GAFI. In addition to the transformation to a floating exchange rate regime (Ali, 2016).

In 2017 and 2018, the FDI inflows decreased due to the decrease in the global FDI inflows and in 2019. Unemployment rate continued to decrease along the last three years as it reached $9.7 \%$ in 2019. The increase in FDI inflow and decrease in unemployment rate was due to some economic reforms that have improved macroeconomic stability and strengthened investor confidence (Ministry of Planning, Monitoring and Administrative Reform). 


\section{3- Data and Methodology}

\section{3-1 Model Specification}

This paper aims to study the relation between FDI and unemployment rate in Egypt in the period from 1990 to 2019 to include the effect of two economic reform programs: the Economic Reform and Structural Adjustment Program and Egypt Vision 2030. Thus, if a relation is to be found between FDI and unemployment, it $\mathrm{ll}$ act as a powerful policy tool to reach the aim of such economic reforms regarding reducing unemployment. However, the period under study will cover up until 2019. Therefore, in an attempt to estimate this relation, this section will estimate an econometric model using the Ordinary Least Squares method (OLS). The general form of the model that to be estimated is

$$
U N E_{t}=\alpha+\beta F D I_{t}+\gamma E X P_{t}+\varphi G G D P_{t}+\omega I N F_{t}+\mu_{t}
$$

Where:

$\alpha$ : Constant term

$\beta, \gamma, \varphi, \omega$ : Slope parameters to be estimated

$U N E_{t}$ : Unemployment rate

$F D I_{t}$ : Net FDI inflows as a percentage of GDP

$E X P_{t}$ : Exports as a percentage of GDP

$G G D P_{t}$ : Annual growth rate of GDP (\%)

$I N F_{t}$ : Annual inflation rate measured by consumer price index $(\mathrm{CPI})(\%)$

$\mu_{t}:$ Random Error

$t$ : Time period

Accordingly, this study will consider unemployment rate as the dependent variable. Then, it will be explained through the OLS model by four control variables: net FDI inflows as a percentage of GDP, exports as a percentage of GDP, growth rate of GDP and inflation rate measured by CPI. Annual Data were collected about the four independent variables and the dependent variable from the World Bank from 1990 to 2019. Nevertheless, to proceed with the analysis, there are number of assumptions that need to be satisfied in order to guarantee the adequacy of the model and the reliability of its results. They are some assumptions to be satisfied in order for the estimated parameters of the model to be BLUE "the Best Linear Unbiased Estimator".

The assumptions requires that the regression is linear in parameters but not necessarily in variables and the values of the regressors and the dependent variable to be independent of the error term. In addition, the error terms must be independent and identically distributed with mean zero and constant variance. The number of observations must be greater than the number of parameters to be estimated. There must be variation in the independent variables. After the model is estimated, those assumptions will be tested in order to affirm the reliability of the estimated parameters. 


\section{3-2 Empirical Results}

Based on the World Bank data, the relation between FDI and unemployment will be empirically investigated by estimating the slope parameters of the model using OLS method depending on the E-views statistical package. Nevertheless, in order to be able to model the data by a simple algebraic model, one assumption must be satisfied, which is stationarity. Therefore, the unit root test was performed to detect the stationarity of each variable. Based on the results of the test shown in table (1), all the variables are stationary at their levels at $5 \%$ significance levels, which in turn allows the estimation of the model.

Since all the variables were found to be stationary, the model presented in equation (1) was estimated. The empirical results as shown in table (2) implied that the fitted regression equation over the period (1990-2019) is:

$$
\widehat{U N E}_{t}=15.98215+0.507769 F D I_{t}-0.147509 E X P_{t}-0.928634 G G D P_{t}+0.025293 I N F_{t}
$$

The estimated model suggests that a $1 \%$ increase in FDI will lead to $0.5078 \%$ increase in the unemployment rate holding other variables constant and is significant at $1 \%$ significance level. On the other hand, both exports and GDP growth had negative significant effects on the unemployment rate at $1 \%$ significance level. Thus, a $1 \%$ increase in exports will lead to $0.1475 \%$ decrease in unemployment rate holding other explanatory variables constant. In addition, if GDP growth increased by $1 \%$, it will cause a decrease in the unemployment rate by $0.9286 \%$ controlling for other variables. Nevertheless, the estimated coefficient for the inflation rate is insignificant at all significance levels. Nevertheless, based on the p-value of the F-statistic, the overall estimated model is statistically significant at $5 \%$ significance level. Moreover, the fitness of the regression model could be measured depending on the value of the R-squared. Based on the results, the R-squared implied that about $63.4 \%$ of the variation in the unemployment rate is explained by the variation in the FDI, exports and GDP growth rate.

From equation (1), it's observed that the model is linear in parameters. In addition that the number of observations, which is 30 , is greater than the number of parameters, which is 5 . However, to insure that the rest of the OLS regression assumptions are satisfied for this study, some diagnostic tests will be implemented including the normality test, heteroskedasticity test and serial correlation test. The results of the normality test shown in table (3) prevailed that the residuals are normally distributed with mean zero at $5 \%$ significance level. In addition, the disturbance terms are assumed be homoscedastic, that is, they have constant variances. Therefore, the Breusch-Pagan-Godfrey test was used and the results of the test viewed in table (4) insures that the error terms are homoscedastic at $5 \%$ significance level. Therefore, it can be concluded from table (3) and (4) that the error terms are normally distributed with mean zero and constant variances. 
Moreover, residuals are assumed to be independent from each other as well as from the explanatory variables and the dependent variable. Using the famous Durbin-Watson statistic table, it was found that based on 4 explanatory variables and 30 observations, the reported Durbin-Watson statistic falls in the region of no decision of autocorrelation, that is $d_{-} l=1.143<1.362<d_{-} u=1.739$. The region of no decision of autocorrelation does not mean there is no autocorrelation. Hence, as a next step, it is necessary to perform a more general test, which is the BreuschGodfrey test for serial correlation (LM test) in the residuals. The test result reported in table (5) and showed that there is no serial correlation at $5 \%$ significance level. Therefore, based on the results of the regression and the diagnostic tests, the assumptions of the OLS regression are satisfied so it can be concluded that the estimated model is adequate and reliable. Nevertheless, if the model results are reliable, then how can the estimated relation between unemployment rate and each of the explanatory variables be explained in light of the Egyptian economy?

The model showed that there is a positive significant correlation between unemployment and FDI. This could be attributed that the largest proportion of FDI in Egypt was directed to the petroleum sector ranging between $53.2 \%$ to $74.1 \%$ during the period from 2011 to 2019 (Central bank of Egypt, different issues). The energy sector is traditionally one of the most capital-intensive sectors, meaning that it requires a lot of capital compared to the amount of labor it employs. Moreover, when FDI is directed to some labor-intensive sectors, it does not have the expected positive impact on the labor market. For instance, although construction and real estate are labor-intensive, they only provide short-term employment and any boost in employment driven by construction might be short-lived and prove unsustainable (The Tahrir Institute for Middle East Policy, 2017). Thus, FDI is associated with higher levels of unemployment rate because it creates only a minimal impact on employment, which fails to absorb the continuous increase in the labor force. This supports the jobless growth theory proposed by Ricardo.

In addition, according to the model results, there exists a negative significant relation between exports and unemployment rate. This is due to the fact that an increase in exports causes an increase in the demand of domestic goods, resulting in increasing the demand for labor, thus reducing unemployment. Moreover, it was estimated that the relation between GDP growth and unemployment rate is a significant negative relation, which is consistent with "Okun's Law". The Law states that in the long run there is negative relation between output growth and unemployment. Thus, Okun's Law is applicable in the Egyptian economy as increased output growth leads to the creation of new jobs (Elshamy, 2013). 
On the other hand, the estimated model prevailed that there is insignificant relation between unemployment rate and inflation rate. The results are consistent with Lucas critique, which implies that raising inflation rate would fail to reduce unemployment rate if it solely depended on historical data and did not take into consideration that workers adjust their expectation to changes in inflation (Touny, 2013). Thus, this insignificant relation can be attributed that inflation expectations plays a significant role in the Egyptian workers labor supply decisions, which in turn prevents inflation rates from affecting unemployment rates. This proves the non-applicability the negative relation proposed by Philips curve in Egypt in the period under study.

\section{4- Policy Recommendations}

Policy makers have always searched for reliable channels to deflate unemployment rate. Thus, relying on the findings of this research paper, some policy recommendations will be suggested to benefit from the relation between unemployment and other control variables as following:

- In order for Egypt to use the increasing FDI to create jobs and reduce unemployment rate, given the fact that it is a labor-abundant developing country, it should be working to attract FDI in labor-intensive industries that relies on local products and expertise in sectors that do not provide only seasonal or short-term employment. This will allow Egypt to boost employment and ensure that some of the new cash reaches local businesses and workers.

- Improving the quality of labor through providing training programs that can improve their skills and add to their knowledge so as to increase the relative competitiveness of the domestic labor and accordingly, increase the foreign demand on them by the MNCs.

- Sustaining the growth of GDP through keeping on the structural economic reform program "Egypt Vision 2030" given that expanding production will help hiring more domestic labor.

- The insignificant relation between unemployment rate and inflation rate can help the CBE in its attempt to reduce the inflation rate, because this insignificant relation mitigates the negative employment impact resulting from reducing unemployment.

- Providing incentives that can increase the demand on the Egyptian exports such as the reduction of tariffs. Nevertheless, the potential of increasing exports depends not only on decreasing trade barriers, but also on many other factors such as the production capacity, the elasticity of the trading partners ' demand and the quality of the domestically produced goods compared to their foreign substitutes. Thus, policy makers should provide export incentives while taking into account these other factors. 


\section{Conclusion}

This research paper aimed to analyze the relationship between FDI and unemployment rate in Egypt during the period (1990-2019). Before analyzing the two variables simultaneously, there was a glance about some of the policies and programs that the Egyptian government has adopted during the period under study for the sake of increasing FDI and decreasing unemployment.

The proposed model was estimated using Ordinary Least Squares method. It was found that there is positive significant relation between FDI and unemployment supporting the Jobless Growth theory because FDI in Egypt was mostly capital intensive. Moreover, FDI in labor-intensive sectors provided only short term employment. On the other hand, there is significant negative relation between unemployment rate and GDP growth rate as well as between unemployment rate and exports while the relation between unemployment rate and inflation rate was insignificant implying the non-applicability of Philips curve in Egypt in the period under study.

That is why, based on the study findings, it was recommended to direct FDI towards labor intensive as well as long run employment industries. In addition to improving the quality of domestic labor in an attempt to increase their demand by MNCs in Egypt. Moreover, the government should provide some incentives so as to increase exports. In addition to keeping the structural reforms on track in order to achieve sustainable GDP growth. Since there is insignificant relation between inflation rate and unemployment rate, this will avail the opportunity to reduce the inflation rate with less damaging effects on the labor market. Nevertheless, there is a question that arises: will Egypt succeed to turn the relation between FDI and unemployment into a negative relation? Or there always be an employment sacrifice in order to increase the level of FDI in Egypt 


\section{References}

- Abouelfarag, H. et al. (2018). The Impact of Foreign Direct Investment on Real Wages in Egypt: A Sectoral Empirical Analysis. Topics in Middle Eastern and African Economies. 20(2). 70-89.

Retrieved from: https://ecommons.luc.edu/

- Akerlof, G. Miyazaki, H. (1980). The Implicit Contract Theory of Unemployment meets the Wage Bill Argument. The Review of Economic Studies. 47(2). 321. https://doi.org/10.2307/2296995

- Aktar, I. Ozturk, L. (2009). Can unemployment be cured by economic growth and foreign direct investment in Turkey? International Research Journal of Finance and Economics. 9(6). Retrieved from: https://scirp.org/reference/referencespapers.aspx

- Alalawneh, M. Nessa, A. (2020). The Impact of Foreign Direct Investment on Unemployment: Panel Data Approach. Emerging Science Journal. Vol. 4, No. 4. http://dx.doi.org/10.28991/esj-2020-01226.

- Ali, R. (2016). Investment Promotion in Egypt: Institutional Analysis of the General Authority for Investment and Free Zones (Published Thesis). The AUC School of Global Affairs and Public Policy, Cairo, Egypt. Retrieved from: dar.aucegypt.edu/handle/10526/4846

- Amer, M. (2012). Active Labor Market Policies: Mapping of Existing Initiatives in Egypt. AFD/World Bank. Retrieved from: https://www.cmimarseille.org/sites/

- Atya, E. (2017). The Effect of Real Exchange Rate on Unemployment Evidence from Egypt. Arab Journal of Administration, 37(4). Retrieved from: https://doi.org/10.21608/aja.2017.17580

- Balcerzak, A. Żurek, M. (2011). Foreign Direct Investment and Unemployment: VAR Analysis for Poland in the Years 1995-2009. Journal of European Research Studies. 14(1). 4-14. Retrieved from: https://econpapers.repec.org/

- Barsoum, G. (2016). Youth Unemployment in Egypt. Global Encyclopedia of Public Administration, Public Policy, and Governance. https://doi.org/10.1007/978-3-319-31816-5_2430-1

- Bayar, Y. (2014). Effects of economic growth, export and foreign direct investment inflows on unemployment in Turkey. Investment Management and Financial Innovations. 11(2). Retrieved from: https://www.businessperspectives.org/

- Bayar, Y. Sasmaz, U. (2017). Impact of Foreign Direct Investments on Unemployment in Emerging Market Economies: A Co-integration Analysis. International Journal of Business and Economic Sciences Applied Research (IJBESAR). 10(3). Retrieved from: https://www.semanticscholar.org/ paper/ 
- Bayar, Yilmaz. Et al. (2020). Unemployment Effects of Greenfield and Brownfield Investments in Post-transition European Union Members. E+M Ekonomie a Management. 23. 4-16. http:// doi.10.15240/tul/001/2020-2-001

- Bielikova, A., \& Paliderova, M. (2017). Impact of foreign direct investments on the economy. New Trends and Issues Proceedings on Humanities and Social Sciences, 3(4). https://doi.org/10.18844/ gjhss.v3i4.1576

- Blanchard, O. (2011). Macroeconomics. Boston: Pearson.

- Brown, A. Koettl, J. (2012). Active Labor Market Programs: How, Why, When, and to What Extent are they Effective? ECA Knowledge Brief. Vol.58. Retrieved from: https://openknowledge.worldbank. org/

- Central Bank of Egypt. (Different years). External position of the Egyptian Economy. Retrieved from: https://www.cbe.org.eg/

- Cherti, H. et al. (2020). Impact of FDI on Unemployment Rate in India. International Journal of Advanced Science and Technology. 29(6). Retrieved from: https://www.ijrte.org/

- Elshamy, H. (2013). The Relationship Between Unemployment and Output in Egypt. Procedia Social and Behavioral Sciences, 81. Retrieved from: https://doi.org/10.1016/j.sbspro.2013.06.381

- Ezzat, A. (2019). The Impact of Foreign Direct Investment on Unemployment: Evidence from Arab countries. Scientific Journal for Economic \& Commerce. 50(1). http://doi.10.21608/jsec.2019.94610

- Folawewo, A. Adeboje, O. (2017). Macroeconomic Determinants of Unemployment: Empirical Evidence from Economic Community of West African States. African Development Review. 29(2). https://doi.org/10.1111/1467-8268.12250

- Garang, A. et.al. (2018). Time Series Bounds Approach to Foreign Direct Investment, Unemployment and Economic Growth in Uganda. Journal of Modern Economy. Vol.9. https://doi. org/10.4236/me.2018.91006

- Golejewska, A. (2001). Foreign Direct Investment and Employment in a Host Country: the Case of Polish Manufacturing. Yearbook of Polish European Studies. Retrieved from: https://www.ce.uw.edu. $\mathrm{pl} /$

- Grahovac, D. Softić, S. (2017). Impact of the FDI on Unemployment Rate in Countries of West Balkan. Review of Innovation and Competitiveness. 3. http://doi.10.32728/ric.2017.32/4

- Haq, T. Zaki, C. (2015). Macroeconomic policy for employment creation in Egypt: Past experience and future prospects (Employment working paper NO.196). International Labor Organization. 
Retrieved from: https://www.ilo.org/

- International Labor Organization. (2017). Towards Evidence-Based Active Labour Market Programmes in Egypt. Retrieved from: https://www.ilo.org/

- International Labor Organization. Decent Jobs for Egypt's Young People: Tackling the Challenge Together. Retrieved from: https://www.ilo.org/

- Irpan, H. et.al. (2016). IMPACT OF FOREIGN DIRECT INVESTMENT ON THE UNEMPLOYMENT RATE IN MALAYSIA. Journal of Physics: Conference Series 710. doi:10.1088/1742$6596 / 710 / 1 / 012028$

- Jude, C. Silaghi, M. (2016). Employment Effects of Foreign Direct Investment: New Evidence from Central and Eastern European countries. Journal of International Economics. 145.

http://dx.doi.org/10.1016/j.inteco.2015.02.003

- Karimov, M. et al. (2020). An Empirical Analysis of the Relationship between Foreign Direct Investment and Unemployment Rate: Evidence from Turkey. European Research Studies Journal. 23(1).

http://doi.10.35808/ersj/1562

- Mahboub, A. (1998). Foreign Direct Investment in Egypt How to encourage and maximize the benefits. Zagazig University. Retrieved from: https://www.researchgate.net/publications

- Masry, M. (2015). Does Foreign Direct Investment (FDI) Really Matter in Developing Countries? The Case of Egypt. Research in World Economy. 6(4). doi.org/10.5430/rwe.v6n4p64

- Ministry of Planning, Monitoring and Administrative Reform. (2018). EGYPT'S VOLUNTARY NATIONAL REVIEW 2018. Retreived from: https://mped.gov.eg/

- Ministry of Planning, Monitoring and Administrative Reform. (2018). Economic Monthly review: September 2020. MAP UNIT. Retreived from: https://mped.gov.eg/

- Nampasa, C. Andrew, P. (2017). Long-run co-integration between foreign direct investment, direct investment and unemployment and South Africa (Working Papers 1714). Department of Economics, Nelson Mandela University, Port Elizabeth, South Africa. Retrieved from: http://repec.mandela.ac.za/ RePEc/mnd/wpaper/paper.1714.pdf

- OECD. (2014). Business Climate Review of Egypt Investment Policies and Public-Private Partnerships. Retrieved from: https://www.oecd.org/ 
- Onanuga, et.al. (2018). Government Policy, Foreign Direct Investment and Unemployment in Emerging Economies. Acta Universitatis Danubius. OEconomica. 14(2). Retrieved from: https:// econpapers.repec.org/.

- Population Council. (2014). Neqdar Nesharek. Retrieved from: https://www.popcouncil.org/ research/neqdar-nesharek

- Radwan, S. (2002). Employment and Unemployment in Egypt: Conventional Problems, Unconventional Remedies. Egyptian Center for Economic Studies (ECES), Working Paper No. 70. Retrieved from: http://www.eces.org.eg/

- Said, M. (2015). POLICIES AND INTERVENTIONS ON YOUTH EMPLOYMENT IN EGYPT. European Training Foundation. Retrieved from: https://www.etf.europa.eu/

- Saleh, D. (2015). FDI and Economic Growth in Developing Countries; A Cross Comparison between Egypt and Turkey. EY International Congress on Economics II: Growth, Inequality and Poverty. Ekonomik Yaklasim Journal. Ankara, Turkey. Retrieved from: www.researchgate.net/ publication/321714894

- Soliman, S. Youssef, Y. (2020). The Reform of Public Business Sector Companies Stipulated by Law No. 203 Of 1991. Sap Egypt Law. Retrieved from: http://sapegyptlaw.com/.

- Stone, A. (2006). Establishing a Successful One Stop Shop: The case of Egypt Presented at IMF/ AMF High-Level Seminar on Institutions and Economic Growth in the Arab Countries Abu Dhabi, United Arab Emirates. International Monetary Fund. Retrieved from: https://www.imf.org/

- The Egyptian Center for Economic Studies. (2020). Views on the Crisis Egypt's Labor Market. Retrieved from: http://www.eces.org.eg/

- The Tahrir Institute for Middle East Policy. (2017). FDI isn`t enough for Egypt. Retrieved from: https://timep.org/

- Touny, M. (2013). Investigate the Long-Run Trade-Off between Inflation and Unemployment in Egypt. International Journal of Economics and Finance, 5(7). https://doi.org/10.5539/ijef.v5n7p115

- UNCTAD. (1998). World Investment Report 1998 Trends and Determinants. New York and Geneva: United Nations. Retrieved from: https://unctad.org/

- UNCTAD. (1999). Investment Policy Review: Egypt. New York and Geneva: United Nations. Retrieved from: https://unctad.org/

- UNCTAD. (2014). World Investment Report 2014: Methodological Note. Retrieved from: unctad.org/ en/ 
- UNCTAD. (2019). World Investment Report 2019. Retrieved from: unctad.org/

- UNCTAD. (2019). World Investment Report 2020: International Production Beyond the Pandemic. Retrieved from: https://unctad.org/

- UNCTAD. (2020). World Investment Report 2020 International Production Beyond The Pandemic. New York and Geneva: United Nations. Retrieved from: https://unctad.org/

- WIDIA, E. et.al. (2019). CAN FOREIGN DIRECT INVESTMENT REDUCE UNEMPLOYMENT IN HOME COUNTRIES? ANALYSIS FOR ASEAN COUNTRY. Jurnal Kajian Ekonomi Islam. 4(2). Retrieved from: http://journal.febi.uinib.ac.id/

- World Bank. (2009). Doing Business Report 2009. Washington, DC: World Bank. Retrieved from: https://www.doingbusiness.org/

- World Bank. (2014). Arab Republic of Egypt More Jobs, Better Jobs: A Priority for Egypt report. Retreived from: https://www.worldbank.org/

- World Bank. (2015). Egypt - Emergency Labor Intensive Investment Project: restructuring. Retrieved from: http://documents.worldbank.org/

- World Bank. (2020). Foreign direct investment, net inflows (BoP, current US\$). World development indicators. https://data.worldbank.org/indicator/BX.KLT.DINV.CD.WD

- World Bank. (2020). Unemployment, total (\% of total labor force) (modeled ILO estimate) - Egypt, Arab Rep." World development indicators. https://data.worldbank.org/indicator/SL.UEM.TOTL. ZS?locations $=E G$ 